\title{
Reproductive Characteristics of Buffaloes: A Review
}

\author{
Agatha Nara Pirondi ${ }^{1}$, Cynthia Maria Carpigiani Teixeira ${ }^{1}$, Erico da Silva Lima ${ }^{1}$, Tiago Neves Pereira Valente ${ }^{2}$, \\ Bruno Borges Deminicis ${ }^{3}$, Fernanda de Campos Bezerra ${ }^{1} \&$ Víctor Libardo Hurtado Nery $^{4}$ \\ ${ }^{1}$ Programa de Mestrado Profissional em Saúde Ambiental, Centro Universitário das Faculdades Metropolitanas \\ Unidas, São Paulo, Brazil \\ ${ }^{2}$ Professor no Instituto Federal Goiano, Campus Posse, Posse, Brazil \\ ${ }^{3}$ Universidade Federal do Sul da Bahia, Ilhéus, Brazil \\ ${ }^{4}$ Facultad de Ciencias Agropecuarias y Recursos Naturales, Universidad de los Llanos, Villavicencio, Meta, \\ Colombia \\ Correspondence: Erico da Silva Lima, Programa de Mestrado Profissional em Saúde Ambiental, Centro \\ Universitário das Faculdades Metropolitanas Unidas, São Paulo, Rua Ministro Nelson Hungria, 541, Vila \\ Tramontano, CEP 05690050, Brazil. Tel: 55-11-33466200. E-mail: erico.lima@fmu.br
}

Received: April 26, 2019

doi:10.5539/jas.v11n13p167

Accepted: June 2, 2019 Online Published: August 15, 2019

URL: https://doi.org/10.5539/jas.v11n13p167

The research is financed by IFGoiano, Go, Brazil.

\begin{abstract}
Interest in buffalo breeding has increased, due to certain advantages in relation to cattle breeding. The objective of this article was to review the reproductive biological characteristics of buffaloes. Buffaloes have their peculiarities regarding the reproductive characteristics, the females are seasonal polyestrous breeders of short days, the puberty's buffalo is reached in ages more than in the bovine, the detection of the estrus is more difficult because of the estrus it happens at dawn and the females of buffalo have few physiological changes producers have difficulty detecting estrus. The gestation period varies between 300 and 320 days. Males have smaller external reproductive organs and less intense sexual behavior in relation to cattle. Buffalo females exhibit reproductive differences such as the hyperpigmented vulva and smaller and lighter, more rigid and tortuously inner structures with more muscle tone. There are some advantages in the creation of buffaloes were evidenced, such as their rusticity and adaptation to areas that would be unsuitableto cattle production, besides counting on products such as milk and meat of good quality. Several protocols of oestrus and ovulation synchronization have been adopted, to improve reproductive efficiency. These protocols have resulted in a pregnancy rates increase of $30 \%$ to $50 \%$. It is concluded that buffalo breeding has space within the animal production system, especially in areas that would be suitable for the breeding of other ruminant species.
\end{abstract}

Keywords: artificial insemination, gestation, puberty

\section{Introduction}

There are approximately 200 million head of buffaloes in the world, milk production has increased $24.5 \%$ in the last decade, and the annual production is 97.5 million tons. An increase in the production of buffaloes using productive breeds Murrah, Jafarabadi, Mediterranean and Carabao distributed throughout the world. The meat of buffalo has important human health benefits, such as lower cholesterol content than beef Bos Taurus, and buffalo milk has higher protein content and lower amounts of somatic cells and a lower cholesterol (Ahmad et al., 2008). The growth of the world buffalo population is due to factors such as milk quality (higher solids content) and meat (lower intramuscular fat content), higher resistance to parasitic infections, especially ticks of the species Rhipicephalus microplus, and intoxications by toxic plants, to the difficult development of diseases commonly observed in cattle, such as infections in the female reproductive tract and mammary gland, with good feed conversion efficiency and the low maintenance requirements of buffaloes that are also profitable for farmers (Phogat et al., 2016). 
It is important to emphasize that better zootechnical indexes have not yet been reached, because these animals are concentrated in regions where there are degraded pastures, which prevents the maximum genetic expression of buffalo reared only on grass (Pipaon et al., 2000).

In recent years, several studies have been carried out to improve the production and quality of buffalo milk, however, many studies have reported, in the last 5 years, aspects and management techniques aimed at improving reproductive efficiency in water buffalo (El-Sisy et al., 2018). This fact indicates that studies on the reproductive characteristics of buffaloes must be taken into account in order to improve production efficiency. To improve reproductive efficiency, several protocols of oestrus and ovulation synchronization have been adopted from their use in commercial cattle production. These protocols yield pregnancy rates of ( $30 \%$ to $50 \%$ ), which are comparable to those achieved in buffaloes breed at natural oestrus. The use of sexed semen in buffalo heifers also showed promising pregnancy rates $(50 \%)$ when compared to conventional non-sexed semen. Supervised reproductive technologies have been transferred to buffalo but the efficiency of these technologies is little adopted by farmers. It offers the opportunity to accelerate the genetic gain in the buffalo industry after improving the technology and reducing its cost. Most buffaloes are kept under the small holder farming system in developing countries. Thus, future research should focus on identify the factors determining low fertility and oestrus behaviour in this species (Warriach et al., 2015).

This article aims to review the main reproductive and management characteristics of buffaloes, describing main points positive and negative aspects of the production system and recent bio techniques, in male and female, have revolutionized and opened avenues for studying and manipulating the reproductive process both in vitro and in vivo in various livestock for improving reproductive efficiency.

\subsection{Male Buffalo}

Compared to cattle, the testicles, accessory sex glands and buffalo penis is smaller. Sexual behavior is similar, but less intense. After "Flehmen behavior" is confirmed the receptivity, exposure of the penis may occur, and the ejaculatory impulse is less intense than in bovine bulls. The buffalo's normal ejaculate is milky-white to yellowish and the appearance looks watery to creamy, depending on the concentration of spermatozoa, rarely exceeding $5 \mathrm{ml}$ (Henry et al., 2017). Male buffalo are more sensitive to thermal stress than females due to their low heat regulation mechanism (Hameed et al., 2016a).

In the buffalo puberty is considered as in many other domestic species the beginning of the production of fertile spermatozoa and libido. The spermatogenesis coincides to the increase of the diameter of the seminiferous tubules (Warriach et al., 2015). When the animal expresses interest in the female, there is also a faster growth of the entire genital system, which makes it capable of fertilizing females in estrus. After this period, the genital system reaches its production of hormones and spermatozoa, producing an ejaculate with characteristics acceptable for freezing, this phase is called sexual maturation, which is achieved around 22 and 24 months of age, in a study with 456 male animals at this age with a minimum weight of $137.5 \mathrm{~kg}$ and a maximum weight of $540 \mathrm{~kg}$ of body weight. By analyzing the andrological evaluation in buffaloes, scrotal circumference (SC) has a fundamental value in the clinical-andrological exam, since it has a positive correlation with body weight and thoracic perimeter, and it is possible to predict the animal's reproductive capacity and its sperm production and their progeny (relation to sexual precocity) (Henry et al., 2017).

It is important to correlate the phenotypic characteristics of the reproductive system with the seminal evaluation, to identify possible pathologies present in the genital system. Environmental factors may interfere with their fertility as well as food availability and ingestion (Ayala 2014).

Animals raised in an intensive environment and semi-intensive studies reach puberty more quickly due to the quality of the feed. The clinical procedure for the andrological examination should consider the peculiarities between the different species. The buffaloes are like those used for all domestic ruminants, the heritable health of the animal is evaluated first, then general health, genital system normality, copulation ability and finally fertilization capacity (Henry et al., 2017).

\subsection{Female Buffalo}

The reproductive behavior of the buffalo species is manifested by the increase in fertility with the reduction of daylight hours (seasonal polyestrous short-day), with greater intensity in the distant sites of the equatorial line, especially to the center-south of the country. The variation in blood concentration of melatonin signals the time of year for buffalo females, is the endocrine signal, determined by the daily amount of sunlight. In equatorial zones, according to Phogat et al. (2016) and Virmani et al. (2018), the female buffaloes present the estrous cycle throughout the year, provided adequate nutrition is provided to maintain reproductive efficiency and to become 
seasonally polyestrous.

Puberty, considering aspects related to feeding and management, present variations from 10 to 36 months among all breeds (Table 1). It is worth mentioning the importance of selection in the herds in order to maintain the animals with the greatest reproductive. In addition, buffaloes present difficulties in detecting estrus, which impairs the determination of puberty. In buffaloes the estrus can keep for 10 to 20 hours during the reproductive period. The estral cycle in buffalo female varies due to several factors, such as management, climate, genetics and feeding, occurring between 16 and 33 days, with a higher concentration between 21 and 24 days. The interval between the onset of estrus and the increase in luteinizing hormone (LH) is from 1 to 12 hours and ovulation occurs between 18 and 40 hours after LH increase. Problems such as hyperprolactinemia (reduction of pulsatile gonadotrophin secretion) are caused by the direct effect of stress and adverse environmental factors on the neuroendocrine configuration. Similarly in cattle, the estrous cycle of the buffalo is divided into four periods, pro-estrus, estrus, metaestrus and diestrous (Ramadan, 2017).

Table 1. Age at puberty (months) of buffalo females in different countries

\begin{tabular}{lll}
\hline Puberty (Months) & Country & Authors \\
\hline $26.5 \pm 6.5$ & Brazil & Vale et al. (1990) \\
$14.2(12.8-16.3)$ & Brazil & Damé e Pimentel (1994) \\
$17.6(14.5-20)$ & Brazil & Vale (2000) \\
$20-24$ & Bulgaria & Ivanov e Zachariev (1960) \\
$35^{*}$ & China & Wang (1979) \\
$10-13$ & Egypt & Hafez (1955) \\
$29^{*}$ & Philippines & Eusébio (1975) \\
$26-36$ & India & Bodhipaksha (1987); Sharma (1987) \\
$26.5 \pm 6.5$ & Italy & Roychoudhury (1969) \\
$20-22$ & Italy & De Franciscis (1979) \\
\hline
\end{tabular}

Note. * Swamp Buffalo/Carabao.

Buffaloes reach puberty around 24 months, weighing between 340-360 kg for animals kept on grass and 400-420 $\mathrm{kg}$ for supplemented animals. The reproductive period in buffaloes is characterized by behavioral, endocrine and reproductive changes occurring during distinct periods of the year. During the non-reproductive season (spring and summer), the greater proportion of light-dark (long days) suppresses estrus behavior and the occurrence of ovulation (Carvalho et al., 2016). Precocious buffaloes at puberty produce more calves and milk in their productive lives, therefore age at first calving is one of the important early economic characteristics that directly influence the production and reproductive efficiency of the animal's age at first calving have an important role in the overall performance of dairy animal production. In addition, the reproductive longevity of buffaloes is higher than in cattle, which can reach 15 years, there are cases of 20 calves during the life. The period of lactation is like that of cattle (Jamal et al., 2017).

The estrus duration is 5 to 27 hours, with an average of 20 hours with ovulation. Ovulation occurs between 24 and 48 hours after the onset of estrus, or 6 to 21 hours after the end of estrus (Campanile et al., 2013).

The adverse effect of the summer season attributed to high ambient temperature impairs the expression of estrus signs, during and length of service. It may also be associated with lower levels of gonadotrophins and lower levels of estradiol during the summer from smaller preovulatory follicles, also associated with low progesterone during the luteal phase, reduced pulsatile secretion, slow follicular growth causing ovulatory follicles and limiting reproductive efficiency, especially in the artificial insemination program (AI) (Qayyum et al., 2018).

Many of the changes in ovary, tubular genitalia, and hormonal secretion in buffaloes are comparable to cattle, for example, the concentration of Progesterone (P4) in plasma and milk that reflects the action of the corpus luteum (CL). However, the levels are lower for cattle (Kumar et al., 2014).

Animals subjected to inadequate feeding and exposed to thermal stress may present silent and ovulatory cysts. During estrus, uterine tone and turgidity are most often observed. The removal of the mucus through the vulva lips has a transparent and sticky appearance at first, changing to cloudy until opaque with the advancement of this state, being an inconstant characteristic and depends very much on the observation of estrus, can also observe the phases of estrus by the amount of LH in the urine (Selvam et al., 2016). 


\subsection{Gestation and Puerperium}

The period of gestation is variable, influenced by the climate, feed, season, and geographical location of the property, but usually varies from 300 to 320 days. The diagnosis of pregnancy in the buffalo is more laborious, due to the rectal contractions stronger than the cow. Gestation usually occurs most commonly in the right horn of the uterine tube. Regarding the diagnosis, it is already possible to be performed after 45 days, with findings like those of the cow, mainly zebu. And from the $22^{\text {nd }}$ day the dosage of Progesterone (P4) in milk or plasma has been performed as a diagnosis of gestation.

Consider acceptable that the female produce two calves every three years. Téllez et al. (2005) report that the 12-month interval between deliveries is physiologically possible and economically advantageous. In the relations between reproductive and productive characteristics of a herd.

When studying the reproductive physiology of buffaloes, Chacur et al. (2018), reported that inadequate management causes problems of embryo absorption and abortion in buffaloes, especially with respect to thermal stress. This problem can be early diagnosed, through a non-invasive technique such as infrared thermography.

The function of the corpus luteum (CL) in the maintenance of pregnancy has not been established, but it is maintained throughout gestation. Plasma levels of Progesterone (P4) remain elevated but decline to baseline on the day of the born. Some buffalo females may exhibit one or more periods of anovulatory estrus, heat usually does not manifest during gestation (Maurya et al., 2017).

To maximize animal production, early diagnosis of gestation and fetal sexing may be used, leading to an increase in the financial return of livestock. In addition, for a detailed study of fetal development, ultrasound can be used, relating the development to the abnormalities and enabling a prognosis of these pregnancies, as well as the correct orientation for the treatment and rapid recovery of pregnant female (Andrade et al., 2017). Between the end of gestation and the beginning of lactation are the most important periods, since it covers the finishing phase and preparation for the birth, and organic and metabolic adaptation to the beginning of a long productive lactation, passing through a puerperium.

To return to pregnancy again, buffaloes need to fast pass to puerperium and a rapid resumption of postpartum ovarian activity without delay in reproductive rates. Females lactating restrictions during the day have a shorter period of service compared to those that always remain with their offspring (Jamal et al., 2017).

The period of service is directly related to the time of born interval, the first estrus and the number of services per conception. Non-genetic factors such as calving, breeding system and seasonality of calving mainly affect the length of service. When labor occurs during the favorable reproductive season, females present a significantly lower postpartum estrus interval when compared to those that have their born outside the reproductive season. During the last 30 days of gestation, the female should be taken to a dry, shaded hygienic picket positioned near the facilities to buffalo observation, parturition and the birth (Hassan, 2017). In the period up to 42 days, the animal is exposed to the pathogenic microorganisms present in the environment, which gradually boost the development of its immune system. Birth weight, as well as in other species, is a productive characteristic of due to its relation with the rate of survival at weaning and weight at the other stages of animal development (Tupinambá et al., 2018).

\subsection{Biotechnology Used in the Reproduction}

In the last decades, several technical have been proposed to manipulate the growth of the ovarian follicle in buffaloes, to be successful in several breeding programs. These hormonal manipulations have been used, which is closely related to ovary, follicular development and ovulation, to optimize reproductive outcomes after the application of various biotechnology (Baruselli et al., 2013a).

In order to enrich the commercial application of reproductive biotechnology, further studies are required, increasing efficiency, reducing costs and enabling large-scale diffusion. Fixed-time artificial insemination (FTAI) has been used in buffaloes in both the unfavorable and favorable breeding season due to their satisfactory pregnancy rates. Other techniques have proved feasible in this species, such as multiple ovulation and embryo transfer, follicular aspiration (FA) and embryo production in vitro, although with less efficiency and little commercial application (Baruselli et al., 2007).

Gutiérrez et al. (2018) reported that a more intensive observation in the follicular rate may increase pregnancy rates by $66.6 \%$ since they were employed with the help of progestogen synchronization protocols

Differences in ovarian dynamics between Bos taurus/indicus and B. Bubalis have been reported, particularly regarding emergence of folicular wave, dominance and folicular size, their comprehension is necessary to 
improve the protocols currently used for manipulation of the estrous cycle, in buffaloes the number of follicles recruited per follicular wave is lower than in the bovine, around two or three (Barros, 2015; Sirois \& Fortune, 1988). However, the growth of the buffalo herd, as it occurs in the other species of zootechnical interest, must be associated with the control of productivity. With the help of reproductive biotechnologies, it is possible to multiply and distribute high genetic animals, collaborating so that the activity becomes increasingly attractive from an economic and social point of view, collaborating in the gains of genetic selection in less time (Kumar et al., 2017).

In their research, Riaz et al. (2019) found that there is an antagonistic effect on the regulation of Follicle Stimulating Hormone Receptor (FSHR) in buffalo and reveals that it may have an association with FSH receptors in buffalo ovaries with the use of melatonin the authors increased the level of mRNA of the buffalo as there was only evidence that the receptor on Melatonin receptor 1 (MT1) in the chorionic gonadotropin (CG) regulated secretions of gonadotrophins from the pituitary gland which in turn controlled the secretion of gonadotrophin hormones or ovarian steroids. FSH and melatonin serve to regulate signaling pathways to their receptors on the ovary, melatonin acts as a direct stimulator in the regulation of both hormones

Luteinizing hormone (LH) improves maintenance and quality of body luteum and melatonin acts as a strong downstream regulator of LH during the luteal phase, decreasing progesterone levels because of the low expression of cholesterol availability (He et al., 2016)

\subsection{Artificial Insemination}

An important biotechnology, among the main uses for domestic species, which allows the multiplication of genetic material, which is indispensable for the breeding of the species. Currently, Fixed-Time Artificial Insemination is a well-established technique with well-established follicular wave and ovulation synchronization protocols for buffalo species, although there is still difficulty detecting estrus due to the estrus behavior in rarely visible buffaloes (Baruselli et al., 2003a; Berber et al., 2002).

It has been known that $\mathrm{AI}$ in post-spontaneous buffalo estrus is a viable strategy for the application of sexed semen (Lu et al., 2015). In a study carried out by the authors, it was observed that this strategy can reduce embryonic losses by obtaining a sexual ratio different from the 1: 1 ratio observed with non-sexed semen, which indicated that the successful separation of $\mathrm{X}$ and $\mathrm{Y}$ spermatozoa was not affected by the bulls, breed or parity of cows, seasonal insemination or technicians.

Insemination with sexed semen in Holstein cows has been shown to be larger (89\%-90\%) than in buffalo, this is attributed to the smaller DNA difference between spermatozoa $\mathrm{X}$ and $\mathrm{Y}$, which is only $3.6 \%$ in buffaloes and, therefore, results in greater overlap between the $\mathrm{X}$ and Y-peak buffalo spermatozoa during calving. The authors also found that the use of Murrah bulls is preferable to produce sexed semen ( $\mathrm{Lu}$ et al., 2015). Because of the difficulty of detecting the estrus, the service rate obtained is still low in artificially inseminated buffaloes, causing the reproductive inefficiency of the herd and compromising the success of the technique. It is also important to note that buffaloes in regions far from the equator show reproductive activity in the autumn and winter months, because they are seasonal animals. Therefore, hormonal protocols have been developed so to allow the use of AI without the need for the detection of estrus, other protocol developed corresponds to clitoral stimulation after AI that would stimulate the neural pathways to release LH and oxytocin thus increasing the rate of conception (Maurya, 2017).

\subsection{The Use of Progestagens}

High incidence of post-partum anoestrus and difficulties in oestrus detection make progestagens a very interesting option for oestrus and ovulation induction in buffaloes (Kumar et al., 2014). These procedures are based on manipulating the CL, either to induce premature luteolysis using prostaglandins or to prolong the luteal phase using progestagens (Figure 1). Thus, it has recently emerged that a more precise manipulation of follicular development may be needed to achieve better synchrony of ovulation and improve fertility. Researchers have therefore turned their attention to evaluating programs in which hormones such as GnRH, FSH, LH, eCG, hCG, prostaglandins, progesterone and estradiol are administered (Baruselli et al., 2001). 


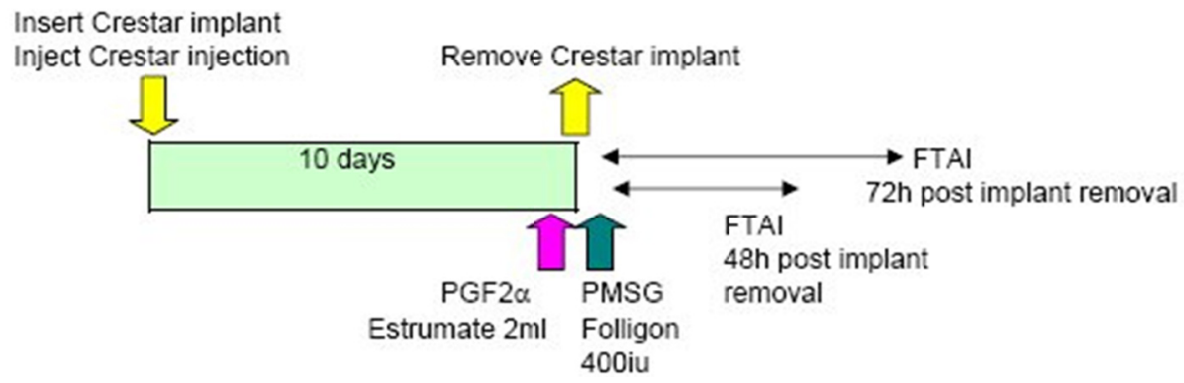

Figure 1. Hormone protocol for IATF

According to Pfeifer et al. (2017) it may be stated that buffaloes respond well to the exogenous administration of hormones, and artificial insemination is possible at a pre-established time after synchronizing ovulation. Most combined hormone protocols give satisfactory pregnancy rates, comparable to those achieved in animals inseminated at natural estrus (Table 2).

Table 2. Insemination pregnancy rates (P/IA) of buffaloes submitted to the IATF protocol based on GnRH and PGF2 $\alpha$ (Ovsynch)

\begin{tabular}{ll}
\hline P/IA Ovsynch protocol, $\%(\mathbf{n} / \mathbf{n})$ & Reference \\
\hline $48.5(133 / 270)$ & Baruselli et al., 2001 \\
$60.3(184 / 305)$ & Berber et al., 2002 \\
$44.3(116 / 262)$ & Baruselli et al., 2003a \\
$48.8(472)$ & Baruselli et al., 2003b \\
$44.4(40 / 90)$ & Neglia et al., 2003 \\
$63.0(131 / 209)$ & Campanile et al., 2005 \\
$27.7(23 / 83)$ & De Rensis et al., 2005 \\
$46.6(166 / 356)$ & Neglia et al., 2008 \\
$52.9(204 / 385)$ & Vecchio et al., 2010 \\
$44.2(138 / 312)$ & Campanile et al., 2011 \\
$61.8(94 / 152)$ & Campanile et al., 2013 \\
\hline
\end{tabular}

\subsection{Follicular Aspiration and in vitro Production}

The follicular aspiration procedure consists of collecting oocytes directly from the ovary, by ultrasound. In vitro production consists of in vitro maturation of collected oocytes for 24 hours, fecundating the gametes and leaving them together for a period of 18 hours, and expect embryonic development for seven to eight days, when it reaches the stage of morula or blastocyst, to be transferred to a receiver. Similar to cattle, in vitro production has great potential for increase herd buffaloes. Although cattle and buffaloes are different species, the techniques developed are the same.

In the study conducted by Konrad et al. (2017), where the authors evaluated Murrah x Mediterranean lactating crosses, they noted that an extension of the ovum pick-up (OPU) interval resulted in larger diameter follicles which reduced oocyte quality, with or without bovine somatotropin treatment (BST) In addition, were population, oocyte retrieval and embryo production were also analyzed (Konrad, 2017). However, some biological and physiological restrictions on buffaloes should be considered about the application of biotechnology related to the production of embryos. An important source of variability of results in the past has been the inconsistent quality of buffalo semen. However, lately, fertilization rates have reached levels like those of cattle, due to the increased preparation of frozen semen. The in vitro production of embryos is a technique that allows to increase the reproductive potential with mating of animals of superior genetics and promotes the genetic advance. In addition, it is an alternative for use in females with reproductive dysfunction and this fact allowed the technique to expand from research to commercial application. Knowledge of ovarian physiology and embryonic development of buffaloes is needed to improve the efficiency of biotechnology production of in vitro embryos. If the oocytes used are obtained from live animals with high genetic potential, the benefits of in vitro can be achieved for 
genetic improvement (Choudhary et al., 2016).

Although the interest in the technique has increase, and because it has be promising mainly for the recovery of oocytes from live animals of various reproductive status (cyclic, prepubertal, pregnant, anestrous), transvaginal follicular aspiration associated with in vitro production have low rates of embryos in buffaloes. The ineffectiveness of the follicular aspiration technique and in vitro in buffaloes presents two main biological problems: low number of follicles in the ovary, which directly influence oocyte retrieval numbers by follicular aspiration and poor oocyte quality (Only $27.3 \%$ to $31.3 \%$ of the recovered oocytes are classified as viable). The first problem may be due to the lower number of follicles recruited per follicular wave. The second problem can be attributed to the fragility of the pellucida zone and the more fragile link between granulosa cells and oocytes than in cattle, interfering in the technique (Campanile et al., 2003).

\subsection{Superovulation (SOV) and Embryo Transfer (ET)}

The use of biotechnologies of Superovulation (SOV) and Embryo Transfer (ET) in the world with buffaloes still present inconsistent results, despite many studies already developed. These results are mainly associated with the low rate of embryo recovery. Stimulating several ovarian follicles in the tertiary stage and stimulating the follicles that would enter atresia, to develop until the preovulatory stage, with subsequent ovulation, can be defined as superovulatory treatment. The increase in ovulation physiologically obtained by this treatment should be complemented with AI (Ashry, 2015). The use of SOV followed by AI is a technique that provides a greater number of embryos per donor (Bó \& Mapletoft, 2014). The application of SOV and AI, associated with embryo transfer (ET) in recipients, are important tools to help the dissemination of high quality genetic material (Baruselli et al., 2011) (Table 3).

The morphological parameters of the follicles and the steroid profile (E2 and P4) in both the plasma and the follicular fluid (FF) in the insuperovulated peri-ovulatory period versus synchronized buffaloes, these authors noted that preovulatory follicle size and FF volume were similar in the two groups studied, the authors report that the decreased steroid concentration in the FF in the period can inhibit the process of ovulation in super ovulated buffaloes, influencing both the process of expansion of the cluster during maturation and relaxation-contraction of the oviduct. They analyzed the expression of genes involved in the cascade of steroids and gonadotrophin receptors in granulosa cells (GCs). In super ovulated buffaloes, FSHR RNA expression in GCs increased, and spleen cascade expression (CYP19A1) also showed a remarkable increase, indicating that treatment with exogenous FSH results in increased aromatase activity which, unexpectedly, did not correspond to increased synthesis of estradiol (Angela et al., 2018).

Table 3. Results of superovulation, embryo collection and transfer in buffaloes monitored by ultrasonography

\begin{tabular}{|c|c|c|c|}
\hline Item & $\begin{array}{l}\text { Group } 1(n=11) \\
\text { FSH/LH } 500 \text { UI* }\end{array}$ & $\begin{array}{l}\text { Group } 2(n=8) \\
\text { FSH/LH } 333 \text { UI* }\end{array}$ & $\begin{array}{l}\text { Group } 3(\mathrm{n}=5) \\
\text { FSH-P } 25 \mathrm{mg} *\end{array}$ \\
\hline $\mathrm{N}^{\mathrm{o}}$ of follicles $(>1 \mathrm{~cm})$ at the end of superovulatory treatment & $14.44 \pm 3.20$ & $13.1 \pm 4.22$ & $8.6 \pm 4.21$ \\
\hline $\mathrm{N}^{\mathrm{o}}$ of ovulations & $8.12 \pm 2.10$ & $8.98 \pm 3.48$ & $7.93 \pm 4.17$ \\
\hline $\mathrm{N}^{\mathrm{o}}$ of CL on the day of the harvest & $7.00 \pm 1.92$ & $6.56 \pm 2.86$ & $7.4 \pm 3.91$ \\
\hline $\mathrm{N}^{\mathrm{o}}$ of follicles $(>1 \mathrm{~cm})$ on the day of harvest & $4.00 \pm 1.29$ & $2.31 \pm 1.87$ & $0.6 \pm 0.89$ \\
\hline $\mathrm{N}^{\mathrm{o}}$ of structures harvested/buffalo & $0.64 \pm 0.81$ & $3.12 \pm 3.94$ & $3.8 \pm 4.14$ \\
\hline $\mathrm{N}^{\circ}$ of embryo transferable/buffalo & 0.09 & 2.56 & 2.8 \\
\hline $\mathrm{N}^{\mathrm{o}}$ of transfers & 1 & 7 & 5 \\
\hline $\mathrm{N}^{\mathrm{o}}$ of gestant receptors & 0 & 2 & 3 \\
\hline
\end{tabular}

Note. * PLUSET, Serono Produtos Farmacêuticos LTDA. ** FSH-P, Schering Corporation.

Super ovulated buffaloes currently produce on average 1 to 3 viable embryos per collection a lower number than embryos recovered in cattle (varies between 8 and 12 total embryos and 4-6 transferable embryos) (Redheda et al., 2018). The SOV and ET techniques, provided by scientific studies on buffaloes, indicate responses to super ovulatory treatment (Salzano, 2017), although the embryo recovery efficiency is lower than the bovine females. The buffaloes may present some flaw in the process of capturing or transporting the oocytes through the uterine tube after superovulation, which leads to a divergence between the two species, bovine and buffalo, in relation to embryo recovery rates (Choudhary, 2016). The objective of using the treatments to induce superovulation in embryo transfer programs is to obtain a high probability of occurrence of pregnancy with the maximum number of viable embryos (Bó \& Mapletoft, 2014). Induction of multiple ovulations is performed after over-stimulation of follicular growth. After the last administration of FSH, gonadotrophin releasing hormone (GnRH) or 
luteinizing hormone (LH), associated with adequate nutrition will ensure the proper development of the follicles for the action of these hormones 24 hours later will result in synchronized ovulation, which eliminates the need for oestrus detection for AI. Administration of the ovulation inducer 24 hours after the last FSH application, demonstrated by previous studies, is associated with higher rates of ovulation, fertilization and embryo recovery (Virmani, 2016).

\section{Conclusions}

But while studies on the reproductive characteristics of buffaloes are increasing, it is necessary to develop further studies so that buffalo breeding will increase the country's economy.

Fixed-time artificial insemination may contribute to the difficulty of detecting estrus. In addition, it is a widely used alternative because it allows the multiplication of high-quality genetic material.

There are other options to accelerate the genetic improvement of the species, such as follicular aspiration and in vitro production techniques, which have been increasing fertilization rates, besides serving as an alternative for females with reproductive dysfunctions, expanding their commercial application.

Superovulation and embryo transfer also facilitate the spread of superior genetic material and increase the likelihood of a higher pregnancy rate, although they still show inconsistent results

\section{References}

Ahmad, S., Gaucher, I., Rousseau, F., Beaucher, E., Piot, M., Grongnet, J. F., \& Gaucheron, F. (2008). Effects of acidification on physico-chemical characteristics of buffalo milk: A comparison with cow's milk. Food Chemistry, 106, 11-17. https://doi.org/10.1016/j.foodchem.2007.04.021

Andrade, R. B., Silva, V. C. F., Silva, A. F., Caldas, S. A., Costa, O. M., Abidu-Figueiredo, M., \& Palhano, H. B. (2017). Avaliação embrionária e fetal por ultrassonografia em fêmeas bovinas leiteiras mestiças submetidas à inseminação artificial ou inseminação artificial em tempo fixo. Brazilian Journal of Veterinary Medicine, 39, 7-19. https://doi.org/10.29374/2527-2179.bjvm342

Angela, S., Carolina, D. C., Floriana, D. R., Alberto, P., Gianluigi, Z., Gianluca, N., \& Bianca, G. (2018). Evaluation of factors involved in the failure of ovum capture in superovulated buffaloes. Theriogenology, 122, 102-108. https://doi.org/10.1016/j.theriogenology.2018.09.007

Ashry, M., \& Smith, G. W. (2015). Application of embryo transfer using in vitro produced embryos: Intrinsic factors affecting efficiency. Castle Pratic-ResearchGate, 23, 1-8.

Ayala, H. D. M., Ribeiro, H. F. L., Filho, S. T., Rolim, Silva, E. V. C., \& Vale, W. G. (2014). Association of testicular echogenicity, scrotal circumference, testicular volume and testosterone concentration in buffaloes. Revista Brasileira de Medicina Veterinária, 38, 334-340.

Baruselli, P. S., Amaral, R., Barufi, F. B., Valentim, R., \& Marques, M. D. O. (2001). Lecirelin and Buserelin (Gonadotrophin releasing hormone agonists) are equally effective for fixed time insemination in buffalo. Brazilian Journal of Veterinary Research and Animal Science, 38, 142-145. https://doi.org/10.1590/S141395962001000300009

Baruselli, O. S., Berber, R. C. D. A., Madureira, E. H., \& Carvalho, N. A. T. D. E. (2003). Half dose of prostaglandin F2a is effective to induce luteolysis in the synchronization of ovulation protocol for fixed-time artificial insemination in buffalo (Bubalus bubalis). Brazilian Journal of Veterinary Research and Animal Science, 40, 397-402. https://doi.org/10.1590/S1413-95962003000600002

Baruselli, P. S., Madureira, E. H., Barnabe, V. H., Barnabe, R. C., \& Berber, R. C. D. A. (2003). Evaluation of synchronization of ovulation for fixed timed insemination in buffalo (Bubalus bubalis)', Brazilian Journal of Veterinary Research and Animal Science, 40, 431-442. https://doi.org/10.1590/S1413-95962003000 600007

Baruselli, O. S., Gimenes, L. U., Carvalho, N. A. T., Filho, M. F. S, Ferraz, M. L., \& Barnabe, R. C. (2007). O estado atual da biotecnologia reprodutiva em bubalinos: Perspectiva de aplicação comercial. Revista Brasileira de Reprodução Animal, 31, 285-292.

Baruselli, P. S., Ferreira, R. M., Sales, J. N., Gimenes, L. U., Filho, M. F. S., Martins, V. C. M., ... Bó, G.A. (2011). Timed embryo transfer programs for management of donor and recipient cattle. Theriogenology, 76, 1583-1593. https://doi.org/10.1016/j.theriogenology.2011.06.006

Baruselli, P. S., Soares, J. G., Gimenes, L. U., Monteiro, B. M., Olazarri, M. J., \& Carvalho, N. A.T . (2013). Control of Buffalo Follicular Dynamics for Artificial Insemination, Superovulation and in vitro Embryo 
Production. Buffalo Bulletin, 32, 160-176.

Barros, D. V., Silva, L. K., Junior, B. L. J., Silva, A. O., Silva, A. G., Franco, I. M., ... Garcia, A. R. (2015). Evaluation of thermal comfort, physiological, hematological, and seminal features of buffalo bulls in an artificial insemination. Tropical Animal Health Production, 47, 805-813. https://doi.org/10.1007/s11250015-0792-9

Berber, R. C. A., Madureira, E. H., \& Baruselli, P. S. (2002). Comparison of two ovsynch protocols (GnRH versus LH) for fixed timed insemination in buffalo (Bubalus bubalis). Theriogenology, 57, 1421-1430. https://doi.org/10.1016/S0093-691X(02)00639-8

Bó, G. A., \& Mapletoft, R. J. (2014). Historical perspectives and recent research on superovulation in cattle. Theriogenology, 81, 38-48. https://doi.org/10.1016/j.theriogenology.2013.09.020

Bodhipaksha, P. (1987). Physiology of female swamp buffalo reproduction. Swamp buffalo reproduction (pp. 117-124). Bangkok: Chulalongkorn University.

Campanile, G., Baruselli, P. S., \& Carvalho, N. A. T. (2003). Effect of feed restriction on ovarian activity and recovered oocyte in Murrah buffalo heifers, Bubalus bubalis (pp. 275-278).

Campanile, G., Gasparrini, B., Vecchio, D., Neglia, G., Senatore, E. M., Bella, A., ... Zicarelli, L. (2011). Pregnancy rates following AI with sexed semen in Mediterranean Italian buffalo heifers (Bubalus bubalis). Theriogenology, 76, 500-506. https://doi.org/10.1016/j.theriogenology.2011.02.029

Campanile, G., Vecchio, D., Neglia, G., Bella, A., Prandi, A., Senatore, E. M., ... Presicce, G. A. (2013). Effect of season, late embryonic mortality and progesterone production on pregnancy rates in pluriparous buffaloes (Bubalus bubalis) after artificial insemination with sexed semen. Theriogenology, 79, 653-659. https://doi.org/10.1016/j.theriogenology.2012.11.020

Carvalho, N. A. T., Soares, J. G., \& Baruselli, P. S. (2016). Strategies to overcome seasonal anestros in water buffalo. Theriogenology, 86, 200-206. https://doi.org/10.1016/j.theriogenology.2016.04.032

Chacur, M. G. M., Dantas, A., Oba, E., Ruedige, F. R., Oliveira, R. A., Bastos, G. P., \& Jorge, A. M. (2018). Thermographic evaluation of the mammary development of buffaloes and their endocrine regulation in different physiological stages. Arquivo. Brasileiro de Medicina Veterinária e Zootecnologia, 70, 450-456. https://doi.org/10.1590/1678-4162-9683

Choudhary, K. K., Kavya, K. K., \& Sharma, R. K. (2016). Advances in reproductive biotechnologies. Veterinary Word, 9, 388-395. https://doi.org/10.14202/vetworld.2016.388-395

El-Sisy, G. A., Mahmoud, K. G. H. M., El-Sokary, A. A. E., Nawito, M. F., \& Ahmed, Y. F. (2018). Factors affecting in-vivo fertility of crossbred Egyptian-Italian buffalo semen. Asian Pacific Journal of Reproduction, 6, 264-267. https://doi.org/10.4103/2305-0500.217341

Hameed, S., Masood, S., Zaneb, H., Khan, M. S., Younis, M., Avais, M., \& Khan, U. R. (2016). Dimensional characteristics of spermatozoa of Nili-Ravi buffalo bulls: Seasonal and climatic influences. Turkish Journal of Veterinary Animal Science, 40, 207-213. https://doi.org/10.3906/vet-1508-56

Hassan, F. A. M., Ali, M. A., Mahmoud, S., \& El-Tarabany. (2017). Economic impacts of calving season and parity on reproduction and production traits of buffaloes in the sub-tropics. Environmental Science and Pollution Research, 1-9. https://doi.org/10.1007/s11356-017-8686-1

He, C. J., Ma, T., Shi, J. M., Zhang, Z. Z., Wang, J., Zhu, K., \& Liu, G. (2016). Melatonin and its receptor MT1 are involved in the downstream reaction to luteinizing hormone and participate in the regulation of luteinization in different species. Journal of Pineal Research, 61, 279-290. https://doi.org/10.1111/jpi.12345

Henry, M., Brito, M. F., Neves, B. P., Auler, P. A., Almeida, J., Andrade, G. O., ... Bergmann, L. (2017). Peculiarities of the buffalo species for andrological evaluation-results of four years of study and weekly semen collection schedule. Animal. Reproduction, 14, 1225-1233. https://doi.org/10.21451/1984-3143AR0005

Jamal, I., Mehla, R. K., Yousuf, S., Naik, M. A., \& Japeth, K. P. (2018). Effect of non-genetic factors on various reproduction traits in Murrah buffaloes. Indian Journal Dairy Science, 71, 193-197.

Konrad, J., Clérico, G., Garrido, M. J., Taminelli, G., Yuponi, M., Yuponi, R., \& Sansinena, M. (2017). Ovum pick-up interval in buffalo (Bubalus bubalis) managed under wetland conditions in Argentina: Effect on follicular population, oocyte recovery, and in vitro embryo development. Animal Reproduction Science, 183, 39-45. https://doi.org/10.1016/j.anireprosci.2017.06.004 
Kumar, P. R., Singh, S. K., Kharche, S. D., Govindaraju, C. S., Behera, B. K., Shukla, S. N., ... Agarwal, S. K. (2014). Andrological examination of buffalos Anestrus in Cattle and Buffalo: Indian Perspective. Advances Animal Veterinary Science, 124-138. https://doi.org/10.14737/journal.aavs/2014/2.3.124.138

Lu, Y., Liao, Y., Zhang, M., Yang, B., Liang, X., Yang, X., ... Lu, K. (2015). A field study on artificial insemination of swamp and crossbred buffaloes with sexed semen from river buffaloes. Theriogenology, 84, 862-867. https://doi.org/10.1016/j.theriogenology.2015.05.022

Maurya, V., Mehrotra, S., Krishbaswamy, N., \& Singh, G. (2017). Effect of clitoral stimulation after artificial insemination on conception and hormonal profile in the Murrah buffalo. Indian Journal of Animal Sciences, $87,70-75$.

Pfeifer, L. F. M., \& Castro, N. A. (2017). Uso de um protocolo de inseminação artificial em tempo-fixo baseado em cinco dias de exposição à progesterona em bubalinos leiteiros. Seminário: Ciências Agrárias, 38, 3927-3932.

Phogat, J. B., Pandey, A. K., \& Singh, I. (2016). Seasonality in buffaloes reproduction. International Journal of Plant, Animal and Environmental Sciences, 6, 46-55.

Pipaon, C. E., Hincapie, J. J., \& Gutiérrez, J. F. P. (2000). Influencia del Medio Ambiente sobre el comportamiento reproductivo de los búfalos de agua. Archivos de Reproducción Animal, 11, 42-45.

Qayyum, A., Arshad, U., Yousuf, M. R., \& Ahmad, N. (2018). Effect of breeding method and season on pregnancy rate and embryonic and fetal losses in lactating Nili-Ravi buffaloes. Tropical Animal Health Production, 50, 555-560. https://doi.org/10.1007/s11250-017-1468-4

Ramadan, T. A. (2017). Role of Melatonin in Reproductive Seasonality in Buffaloes. Theriogenology, 88-107. https://doi.org/10.5772/intechopen.69549

Redheada, A., Siewb, K., Lambiec, N. N., Carnarvonc, D., Ramgattieb, R., \& Knightsa, M. (2018). The relationship between circulating concentration of AMH and LH content in the follicle stimulating hormone (FSH) preparations on follicular growth and ovulatory response to superovulation in water buffaloes. Animal Reproduction Science, 188, 66-73. https://doi.org/10.1016/j.anireprosci.2017.11.010

Riaz, H., Yousuf, M. R., Liang, A., Hua, H. G., \& Yang, L. (2018). Effect of melatonin on regulation of apoptosis and steroidogenesis in cultured buffalo granulosa cells. Animal Science Journal, 1-8.

Salzano, A. (2017). Analysis of factors affecting embryo recovery in superovulated buffaloes (p. 104, Tesi Dottorato, Universita' Degli Studi di Napoli “Federico II", Triennio).

Selvam, R. M., Onteru, S. K., Nayan, V., Sivakumar, M., \& Singh, D. (2016). Exploration of Luteining Hormone in Murrah Buffalo (Bubalus bubalis) Urine: Extended Surge Window Opens Door for Estrus Prediction. General and Comparative Endocrinology, 251(15), 1-6. https://doi.org/10.1016/j.ygcen.2016.12.002

Téllez, M. B., Meléndez, Y. A., Martinez, A. M., Figueiras, N. B., Mendoza, M. M., \& Sánchez, M. M. (2005). Influencia de la época y región en algunos indicadores reproductivos del búfalo de agua (Bubalus bubalis) en el territorio oriental de Cuba. Revista Electrónica de Veterinaria, 6.

Tupinambá, G. S., Valente, T. N. P., Ribeiro, J. C., Santos, W. B. R., Cezário, A. S., Lima, E. S.,... Camargos, A. S. (2018). Influence of type of birth and sex on weaning weight of dorper crossbred lambs. Journal of Agricultural Science, 10, 492-496. https://doi.org/10.5539/jas.v10n7p492

Virmani, V. M., Malik, R. K., \& Singh, P. (2016). Effect of gonadotropin releasing hormone (Gnrh) preparations on induction of estrus and fertility in buffaloes under field conditions in Haryana. Buffalo Bulletin, 35, 93-100.

Virmani, V. M., Malik, R. K., Vijayalakshmy, K., Singh, P., \& Chhikara, S. K. (2018). Management of anoestrus murrah buffaloes using two different hormonal approaches. International Journal Current Microbiology and Applied Science, 7, 3427-3437. https://doi.org/10.20546/ijcmas.2018.701.404

Warriach, H. M., McGill, D. M., Bush, R. D., Wynn, P. C., \& Chohan, K. R. (2015). A Review of Recent Developments in Buffalo Reproduction-A Review. Asian-Australasian Journal of Animal Sciences, 28, 451-455. https://doi.org/10.5713/ajas.14.0259 


\section{Copyrights}

Copyright for this article is retained by the author(s), with first publication rights granted to the journal.

This is an open-access article distributed under the terms and conditions of the Creative Commons Attribution license (http://creativecommons.org/licenses/by/4.0/). 